\title{
A Magyar Természettudományi Múzeum Őslénytani és Földtani Tárának Vizsgálatiminta Gyüjteménye
}

\author{
Dulai Alfréd, Gasparik Mihály \& Szives Ottilia* \\ Magyar Természettudományi Múzeum, Öslénytani és Földtani Tár, \\ 1083 Budapest, Ludovika tér 2-6., Magyarország \\ E-mail:dulai.alfred@nhmus.hu,gasparik.mihaly@nhmus.hu,szives.ottilia@nhmus.hu
}

\begin{abstract}
Összefoglalás - A Magyar Természettudományi Múzeum Őslénytani és Földtani Tára 2011ben alakította ki a Vizsgálatiminta Gyüjteményt. Ebbe nagyrészt olyan üledék- és kőzetminták, iszapolási minták és fúrómag minták kerültek, amelyek ősmaradványokat tartalmaznak/ tartalmazhatnak, de azok elkülönítése, kiválogatása még nem, vagy csak részben történt meg. Az egyszeri és megismételhetetlen mélyfúrásokból, az egykori nyersanyagkutató programokból származó minták felszínre hozatala ma már nem kivitelezhető, a gyűjtemény értéke ezért felbecsülhetetlen, eszmei és tudományos értéke kiemelkedően magas. A szokásos gyűjteményi felosztást követve gerinces és gerinctelen gyűjteményi részekre különül a Vizsgálatmina Gyűjtemény, melyeken belül kronosztratigráfiai sorrendben, földrajzi régiók szerint tároljuk az anyagokat. A gyűjtemény gerinces maradványokat tartalmazó részét főként mikropaleontológiai anyagok alkotják, melyek jó része szintén ma már nem gyűjthetőlelőhelyekről, példáulbarlangokból származik. Tudományos ismeretterjesztő célokra, múzeumpedagógiai foglalkozásokra, múzeumi közönségprogramokra is rendszeresen felhasználjuk a Vizsgálatmina Gyüjtemény egyes részeit, így még szélesebb az a paletta, ami a gyűjtemény értékét és fontosságát mutatja. Részben a Magyar Természettudományi Múzeum elhelyezési problémáival összefüggésben, időről-időre felmerül a gyűjteményi terek szűkössége és ezzel összefüggésben a feldolgozatlan, és emiatt külső szemlélők és döntéshozók által tévesen értéktelennek vélt gyűjteményrészek selejtezésének ötlete. Cikkünkkel többek között azt szeretnénk demonstrálni, hogy milyen értékektől fosztaná meg egy-egy ilyen selejtezés nem csak a múzeumot, hanem a hazai és a külföldi tudományos közösséget és tágabb értelemben az őslénytan és földtan iránt érdeklődő nagyközönséget is.
\end{abstract}

Kulcsszavak - fosszília, múzeum, gyűjtemény, iszapolási minta, mélyfúrás

* levelező szerző. 


\section{A VIZSGÁLATIMINTA GYÜJTEMÉNY TÖRTÉNETE ÉS KIALAKÍTÁSÁNAK SZEMPONTJAI}

A Magyar Természettudományi Múzeum (MTM) Öslénytani és Földtani Tára 2010-ben átalakította gyüjteményi anyagainak leltározási rendjét. Az addigi gyakorlat szerint minden beleltározott tétel egyedi leltári számot kapott, ami egyes esetekben problémát okozott. A gyakran tömeges megjelenésü gerinctelen és kisgerinces ösmaradványok esetében az egyes példányok nem kezelhetők olyan egyedi tételként, mint például egy festmény vagy egy régészeti lelet (melyekre az egyedi nyilvántartás szabályait kidolgozták). Az egyes lelőhelyeken százszámra gyüjthető fajok példányait nem célszerủ olyan szigorú szabályok szerint kezelni, mint egy valóban egyedi és pótolhatatlan műalkotást. Ezért 2011-től csak a kiemelkedően szép, esetleg nagy értékủ anyagok, valamint a típuspéldányok kerülnek egyedi leltározású tételként a nyilvántartásba. Az egyedi nyilvántartású leltári tételeket tartalmazó gyüjteményi rész Gerinces és Gerinctelen Paleontológiai Gyüjtemény néven szerepel a MTM gyüjteményi rendszerében. 2011-től kezdve a kiválogatott, valamilyen rendszertani szintig (faj, nemzetség, család) meghatározott, de nem kiemelkedő értéket képviselő példányok az újonnan létrehozott, szekrénykataszteri nyilvántartású Rétegtani Gyüjteménybe kerülnek.

Ugyancsak 2011-ben került kialakításra egy harmadik gyüjtemény, a Vizsgálatiminta Gyüjtemény (VMGY). Ebbe a gyüjteménybe olyan üledékés kőzetminták, iszapolási minták és fúrómag minták kerültek, amelyek ősmaradványokat tartalmaznak/tartalmazhatnak, de azok elkülönítése, kiválogatása még nem, vagy csak részben történt meg. Ezek tipikusan olyan gyüjteményi tételek, amelyek kevéssé látványosak, kiállításra, vagy egyéb közmüvelödési célra csak részben alkalmasak, elsősorban tudományos jelentőséggel rendelkeznek, ezért ebben az esetben is a szekrénykataszteri nyilvántartás alkalmazása indokolt. Ugyanakkor érdemes azt is megemlíteni, hogy az időközben megszűnt lelőhelyekről, vagy különösen az egyszeri és megismételhetetlen mélyfúrásokból származó minták eszmei és tudományos értéke kiemelkedően magas.

$\mathrm{Ez}$ a gyűjtemény jellemzően zsákokban, zacskókban vagy fiolákban lévő, még ki nem válogatott üledékes kőzeteket tartalmaz. Az elektronikus adatbázisban nyilvántartott gyüjteményi tételeinek darabszáma 2020 végén 27385 . A gyüjtemény valós nagysága azonban messze meghaladja ezt a számot, hiszen a VMGY 2011-es kialakításakor nagyon sok korábban bekerült minta várt a nyilvántartásba vételre, és az elmúlt években is nagy tételszámú anyagok kerültek a gyüjteménybe, melyek nyilvántartásba vétele jelenleg is folyamatban van. Az előzetes becslések szerint a gyüjtemény mintegy 70.000 tételt (mintát) tartalmazhat. A példányszám azonban milliós nagyságrendủ lehet, hiszen egy-egy minta akár több száz vagy több ezer apró ősmaradványt is tartalmazhat (például egysejtű foraminiferát a gerincteleneknél, vagy kígyócsigolyát a gerinceseknél). 


\section{A VIZSGÁLATIMINTA GYÜJTEMÉNY FELÉPÍTÉSE}

A VMGY felépítése - az egyedi leltározású gyűjteményhez hasonlóan - az őslénytani gyüjtemények klasszikus tagolását követi: a gerinces és gerinctelen anyagokat tartalmazó üledékek külön kerültek elhelyezésre kronosztratigráfiai sorrendben, földrajzi régiók szerint tárolva. Az elkülönítés azonban időnként problémás, hiszen a jellemzően gerinctelen maradványokat tartalmazó tengeri üledékekben is előfordulhatnak, sőt esetenként gyakoriak a gerinces fosszíliák (például cápafogak, csontoshal fogak, otolithok azaz a hallókövek). Ennek a fordítottja is igaz: az uralkodóan gerinceseket tartalmazó szárazföldi minták (például jégkorszaki barlangi üledékek) is majdnem mindig tartalmaznak szárazföldi csigákat, vagyis gerincteleneket. Sokkal könnyebb, gyorsabb és átláthatóbb a gyüjtemény kezelése és áttekintése az elkülönített gerinces/ gerinctelen csoportosításban még a mai, digitális alapú nyilvántartási rendszer mellett is. A szekrények ajtajának belső oldalán a múzeumi törvény előírásainak megfelelően egy szekrénykataszteri összegzőlapon szerepelnek az itt elhelyezett tételek fiók szerinti bontásban. A fiókok rendjében a tételmozgást, vagy bármiféle változtatást a szekrényajtó belső oldalán található szekrénykataszteri munkalapon rögzítjük. Az egyes fiókok címkéin a rendszerezés szempontjai szerint szerepel a fiókban lévő anyag megnevezése (1. ábra).

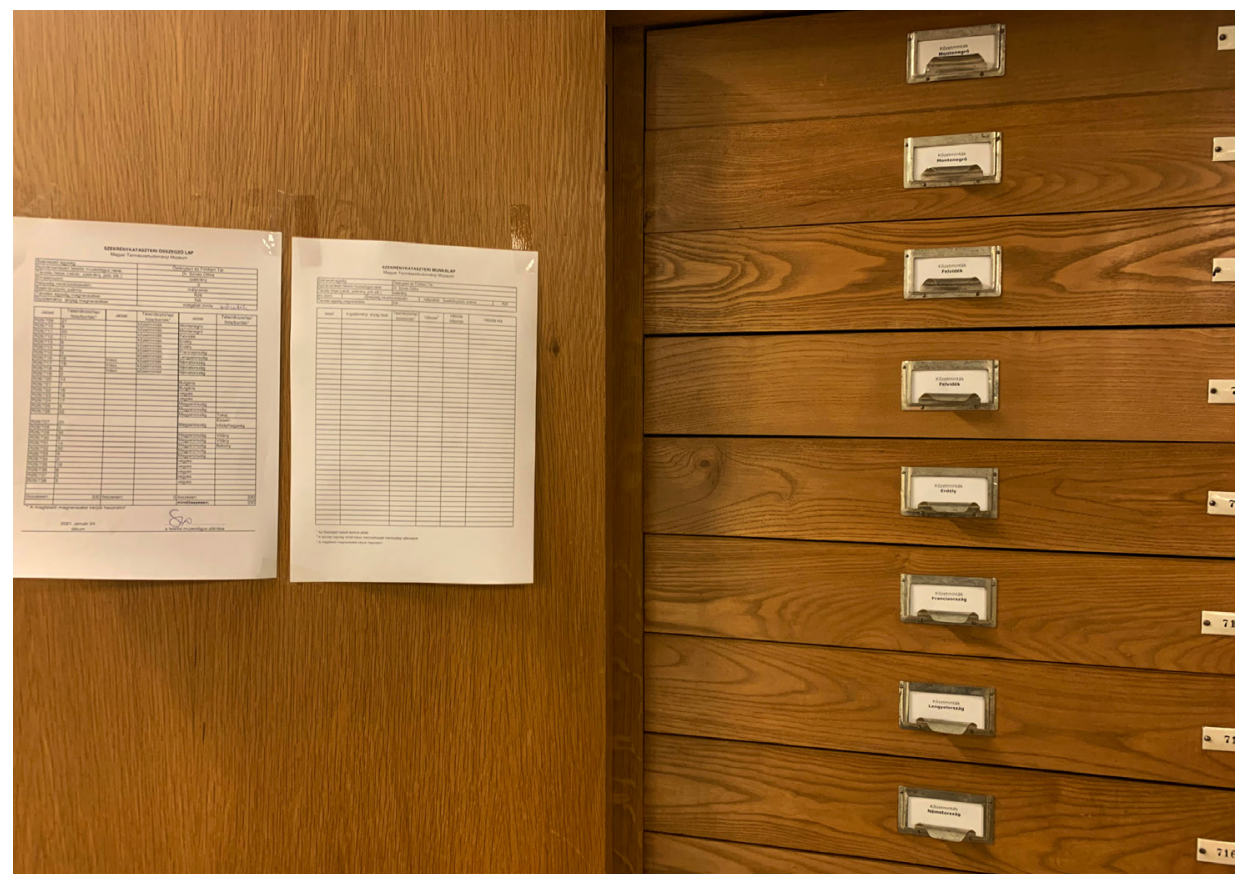

1. ábra. A Vizsgálatiminta Gyűjtemény szekrénykataszteri elhelyezési rendje és dokumentációja. 


\section{Gerinces anyagok}

A gerinces anyagokat tartalmazó vizsgálatiminta anyag jellegében némileg eltér a VMGY gerinctelen részétől, itt ugyanis sok esetben nem csak üledék- vagy kőzetminták, hanem részben már kiválogatott és szortírozott maradványok is nagy tételszámban vannak. Ezek (egyelöre) még nem a Rétegtani Gyűjteményben kaptak helyet, ugyanis a legtöbb ilyen anyagra még komoly feldolgozó munka vár. Ennek fö oka, hogy nem csak a múzeumban, de Magyarországon is túl kevés a gerinces paleontológus ahhoz, hogy minden földtörténeti korszakra és minden állatcsoportra legyen olyan specialista, aki kellő pontossággal tudná beazonosítani egy-egy lelőhely példányait. Amíg ez a taxonómiai feldolgozás nem készül el, az egyedi nyilvántartású gyűjteménybe (Gerinces és Gerinctelen Paleontológiai Gyüjtemény) való elhelyezésük semmi esetre sem indokolt. Sokszor azonban még a VMGY-hez hasonlóan szekrénykataszteri nyilvántartású, de annál jobban feldolgozott Rétegtani Gyüjteménybe sem érdemes átsorolni őket, praktikusabb ideiglenesen a VMGY-ben tartani. Annál inkább hasznos ez a megoldás, mert így egy-egy lelőhely leletanyaga egy helyen marad, ami megkönnyíti a feldolgozó munkát, és a további nyilvántartási munkát is (2-3. ábra).

A VMGY gerinces anyagának legnagyobb része az Őslénytani és Földtani Tár egykori vezetője és gerinces paleontológusa, Jánossy Dénes 1960-as és 70-es évekbeli (kisebb részben ennél későbbi) gyűjtéseiből származik. A teljeség igénye nélkül - csak a legfontosabb vagy legismertebb lelöhelyeket felsorolva - ide tartoznak a régi, klasszikusnak mondható lelőhelyekről (például Somssich-hegy, Csarnóta, Osztramos, Beremend, Villány, Nagyharsányhegy, Dunaalmás, Süttő és Vértesszőlős), valamint a Subalyuk-, Peskő- és Szarvaskői-barlangból, illetve az Upponyi- és Tarkői-kőfülkéből gyüjtött anyagok (JÁnOssy 1979). Ezeken kívül egyéb lelőhelyek anyaga is itt kapott helyet, pl. a Pilis-barlangból és a Spirálbarlangból előkerült tömeges denevér leletanyag.

A gyüjteményt tovább gyarapította tárunk egyik jelenlegi gerinces paleontológusa, Gasparik Mihály, aki főleg villányi-hegységi (Beremend, Villány-Templomhegy) és gerecsei (Tokod, süttői Cukor-bánya és Gazda-bánya) gyüjtéseket végzett. A legutóbbi gyüjtések (Süttő, Gazda-bánya; 2017-2019) során begyűjtött, részben még iszapolásra váró, fel nem dolgozott több tonnányi üledékanyag is ebben a gyüjteményben került elhelyezésre. Ennek az anyagnak a nagy része még zsákokban várja a további feltáró, preparáló munkákat. Viszonylag jelentős az a leletanyag is, amit barlangászok hoztak be feldolgozásra az Öslénytárba, vagy az őslénytári munkatársak (Jánossy Dénes, Gasparik Mihály, Hankó Eszter) barlangászokkal történt közös gyüjtései révén kerültek be a gyüjteménybe. Ilyen például a solymári Ördöglyuk-barlangból és több, az Aggteleki Nemzeti Park területén található barlangból gyüjtött üledék- és leletanyag. Szintén a gerinces mintagyüjteményt gazdagítja Bosnakoff Mariann részben már publikált fosszilis hal-hallócsont, vagyis otolith gyüjteménye (Bosnakoff 2011). 


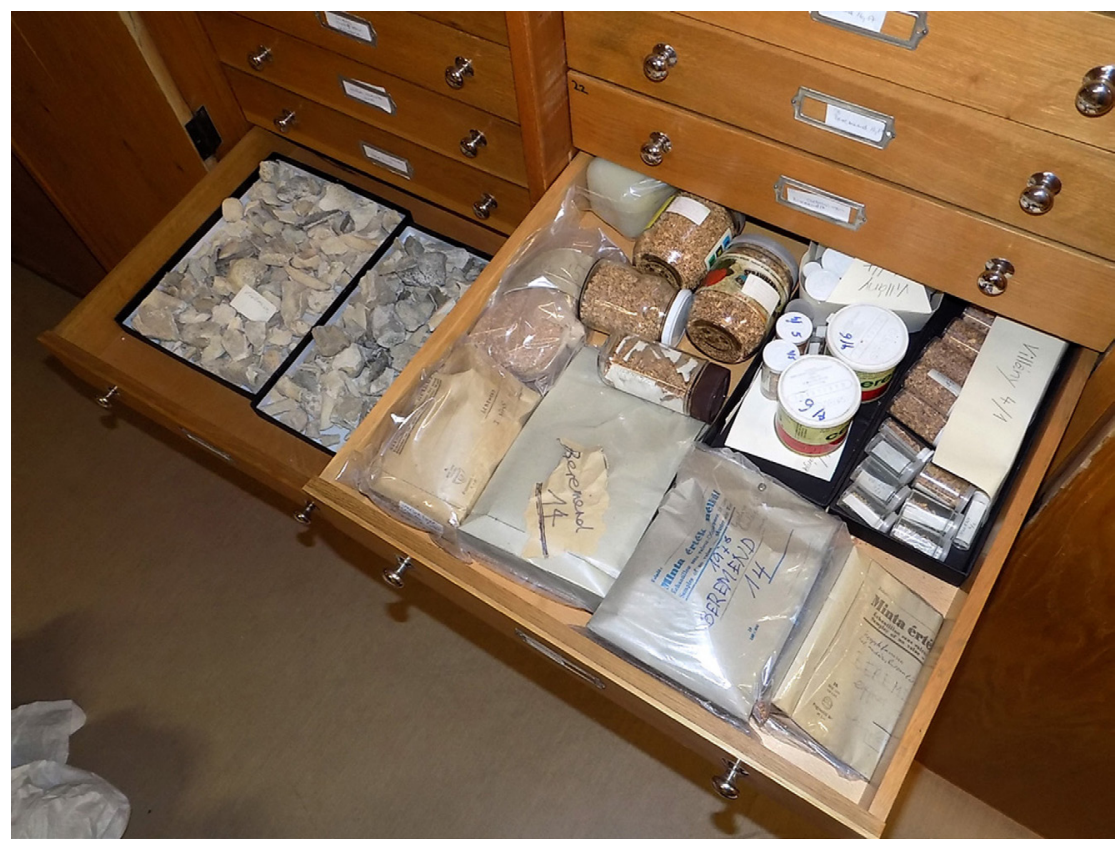

2. ábra. Vértesszőlősi és beremendi anyagok a Vizsgálatiminta Gyűjtemény gerinces gyüjteményrészében.

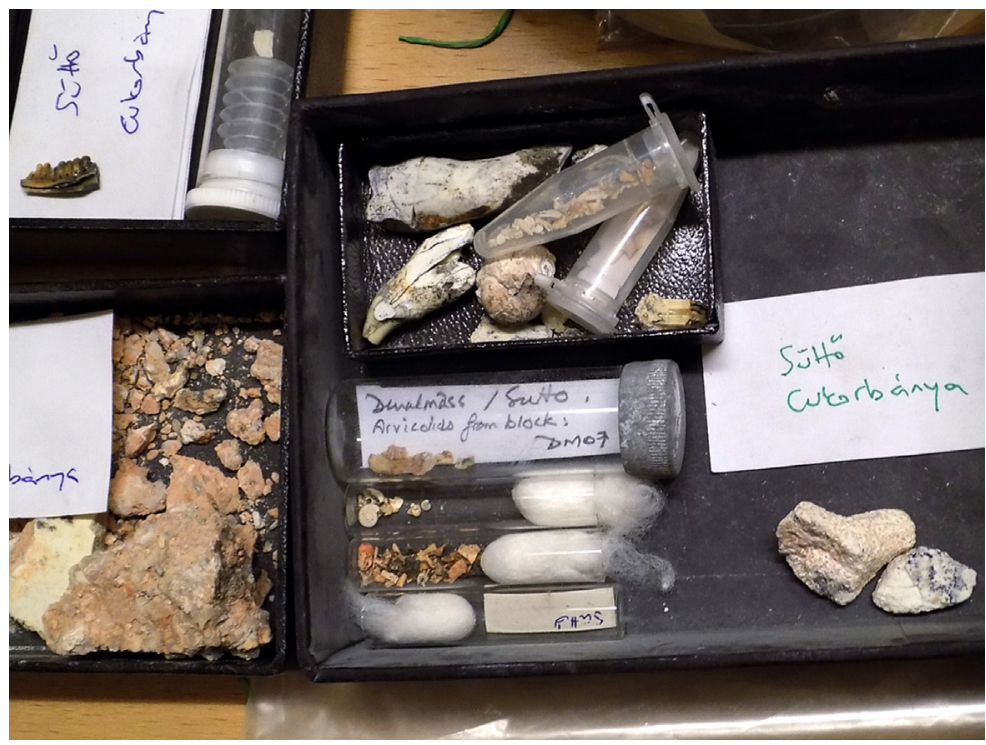

3. ábra. Részlet a süttői Cukor-bánya anyagának feldolgozási fázisaiból: David Mayhew által szétválogatott és részben meghatározott anyag. 
A VMGY leiszapolt gerinces anyagmintáit gondosan kiválogatjuk és az előkerült maradványokat meghatározzuk. A kiválogatott, és taxonómiai vizsgálat után rendszertani szempontból rendezett anyagok átkerülnek a Rétegtani Gyüjteménybe, ahol szintén szekrénykataszteri nyilvántartásba vesszük őket. Az esetlegesen előkerülő kiemelkedő értékű tételeket (például egy új faj típuspéldányait) publikálás után a Gerinces és Gerinctelen Paleontológiai Gyűjtemény egyedi leltározású tételei közé helyezzük át.

\section{Gerinctelen ősmaradványok}

A gyüjtemény gerinctelen ősmaradványokat tartalmazó üledékanyagai többnyire a régi múzeumi szekrényben kerültek elhelyezésre, a gyüjtemény elrendezése földtörténeti korok szerint, ezen belül pedig földrajzi elhelyezkedés szerint halad. Adományozott nagyobb gyüjtemények esetén a teljes gyüjteményt egyben tartjuk, és ezen belül alakítjuk ki a gyüjteményi rendet a fent említett módon.

A VMGY földtörténeti szempontból legidősebb részei a bükki paleozoikumból származó, valamint a Mecsek és a Dunántúli-középhegység triászjura-kréta korú mintáiból állnak.

Dunántúli-középhegység anyagai közt található a méltán világhírủ Balatonfelvidéki triász üledékes mintagyüjteménye is, melyeket többek közt Aszófö, Balatonarács, Csopak, Halimba, Öcs-Pula, Újdörögd-puszta, Veszprém és Litér lelőhelyeiről gyüjtöttek az Öslénytani és Földtani Tár, valamint a Magyar Bányászati és Földtani Hivatal (régebben Magyar Állami Földtani Intézet) munkatársai (VöRös 1998, 2003, 2018). Ezen kívül a Dunántúli-középhegységből még Gánt, Csór és Iszkaszentgyörgy mellől gyüjtöttek mintákat a Tár egykori és jelenlegi kollégái. Kisebb triász korú anyagok találhatók a gyüjteményben a Pilisből és a Budai-hegységből, valamint Csővár és Romhány mellől. A bükki triász korú üledékek Felsőtárkány, Felnémet és Cserépfalu, Szár-hegy mellől származnak, míg az ország déli részéből (Mecsek és Villányi-hegység) Bükkösd, Hetvehely, Orfü, Pécs, Szava és Zuhánya-bánya mellől vannak anyagok a gyüjteményben.

A Vizsgálatiminta Gyűjtemény kiemelkedő részét alkotják a lábatlani Bersek-hegy (Főzy 2013), és a bakonyi jura-kréta korú szelvények anyagai (5. ábra), valamint a ma már természetvédelmi védettséget élvező, nem gyüjthető tatai Kálvária-domb Geoparkból (SzIves 2007) két évtizede a tár dolgozói által gyüjtött és feldolgozott kréta üledékanyag.

A mezozoós gerinctelen gyüjtemény részét képezik Pálfy József akadémikus anyagai, aki a világ számos pontján folytat jelenleg is kutatást. Ezek közt délamerikai (6. ábra), kanadai és szlovák szelvények tudományos igénnyel, réteg szerint gyüjtött eredeti kőzetmintáit is megtalálhatjuk. A már publikált ősmaradványok egyedi leltári számmal a Gerinces és Gerinctelen Paleontológiai Gyüjteményben kerültek elhelyezésre. 
A VMGY gerincét és mintáinak legnagyobb részét az úgynevezett „Eocén programhoz”, valamint egyéb nyersanyagkutató projektekhez kapcsolható egykori mélyfúrások eocén korú fúrási mintái adják (7. ábra). A Dunántúliközéphegységre koncentrálódó kőszénkutató fúrások hatalmas tömegü mintaanyagánaknagyforaminiferáitKecskeméti Tibor dolgoztafel(KECSKEMÉTI 1970, 2019a, b), de a begyüjtött fúrásminták egyéb ősmaradványait (például a brachiopodákat) is intenzíven kutatták (BITNER \& DUlai 2008; DUla i 2019a). Schréter Zoltán eocén-miocén korú, északi-középhegységi fúrási minta anyagai is ebben a gyüjteményben kerültek elhelyezésre.

A gerinctelen vizsgálatiminta anyagok kiemelkedő részét alkotja a Kókay Gyüjtemény, melynek történetét és anyagait korábban részletesen ismertettük (DULA I 2015). Kókay József geológus miocén korú fúrási minta anyagainak nagy része a Várpalotai-medencéből és budapesti lelőhelyekről származik (8. ábra). Életének jelentős részében a Várpalotai-medence miocén kőszénkutatásával foglalkozott, így érthető, hogy a várpalotai feltárásokból, és főleg fúrásokból származó anyaga 71 fiókot tölt meg. Még jelentősebb az inotai fúrásokból származó mintagyüjtemény (118fiók). A teljes Kókay Gyűjtemény mintegy 8100 tételt tartalmaz, és 534 fiókot tölt meg.

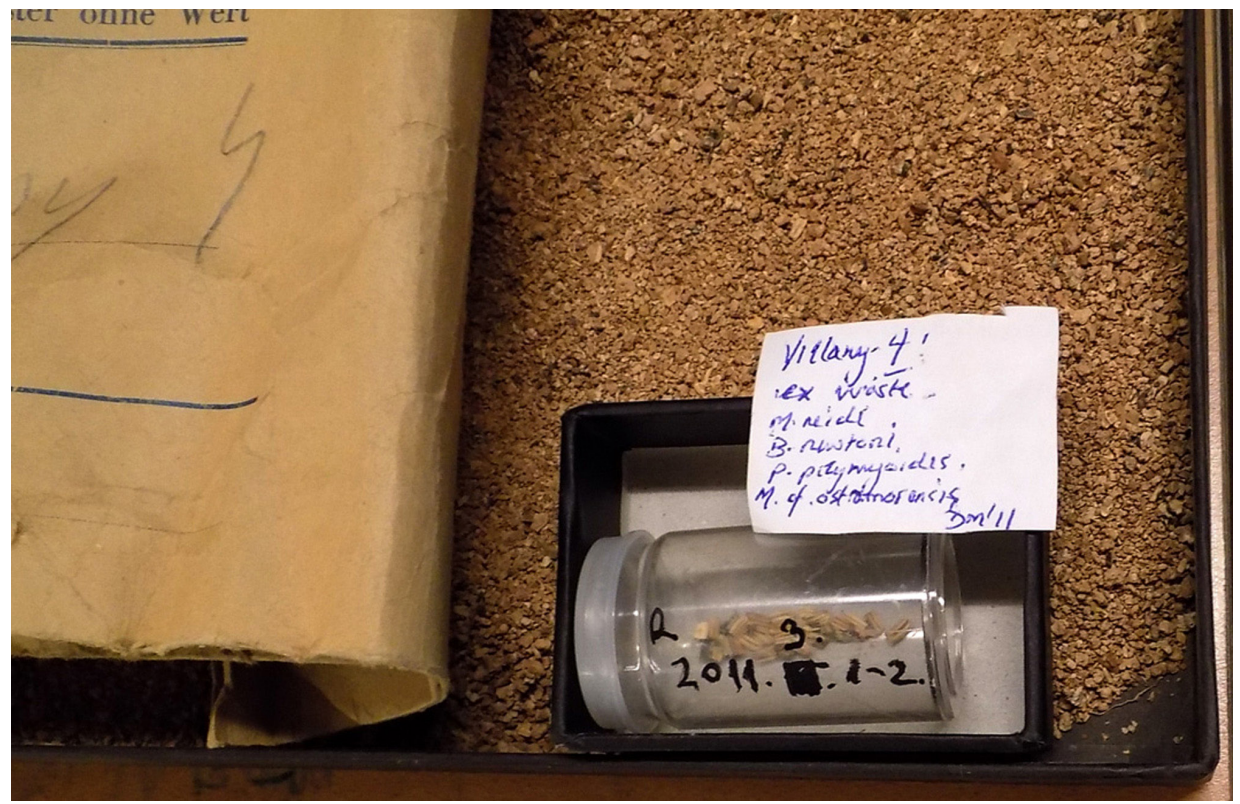

4. ábra. A Vizsgálatiminta Gyűjtemény anyagán külföldi szakértők is dolgoznak: David Mayhew által határozott kisemlős anyag a Villány 4-es lelőhelyről. 


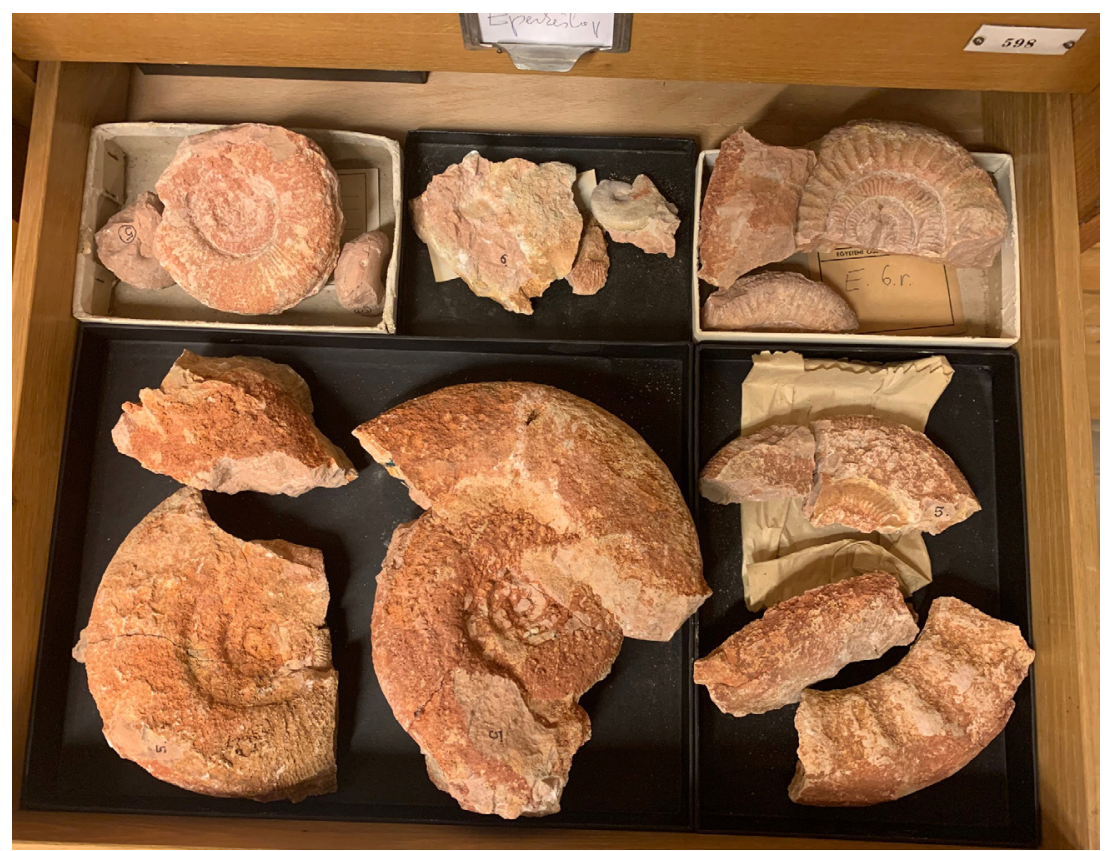

5. ábra. A Zirc melletti Eperkéshegy késő-jura korú ammoniteszei (Főzy István gyűjtése).

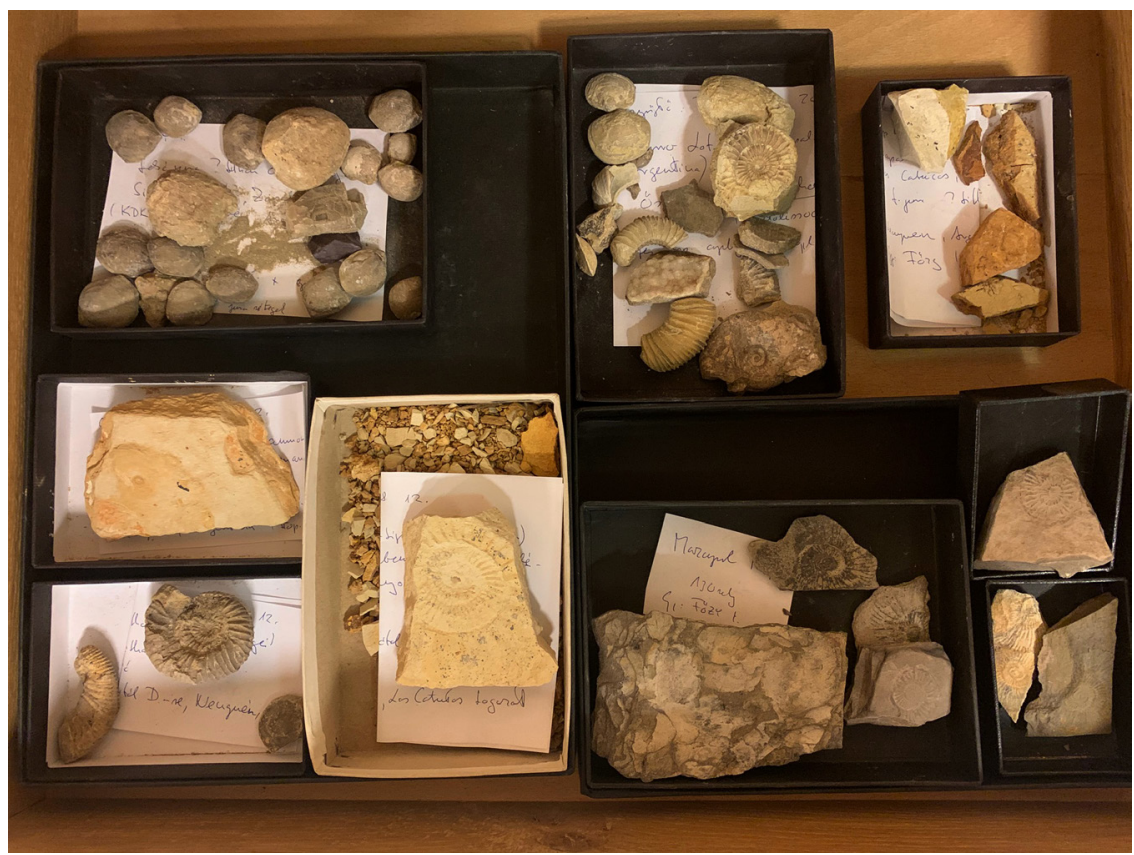

6. ábra. Mexikóban és Argentínában gyüjtött ammoniteszek, Pálfy József és Főzy István gyűjtése. 


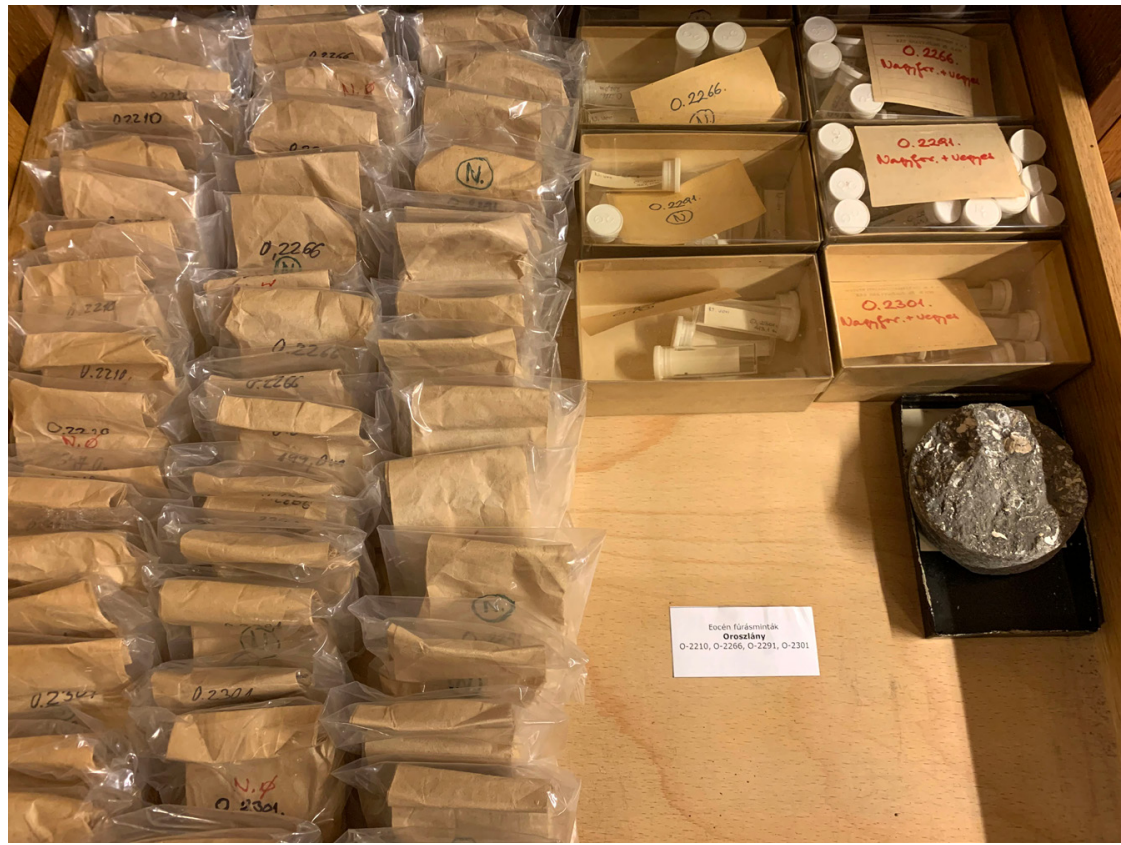

7. ábra. Kiválogatott és meghatározott eocén korú fúrási minták (Kecskeméti Tibor gyűjteménye).

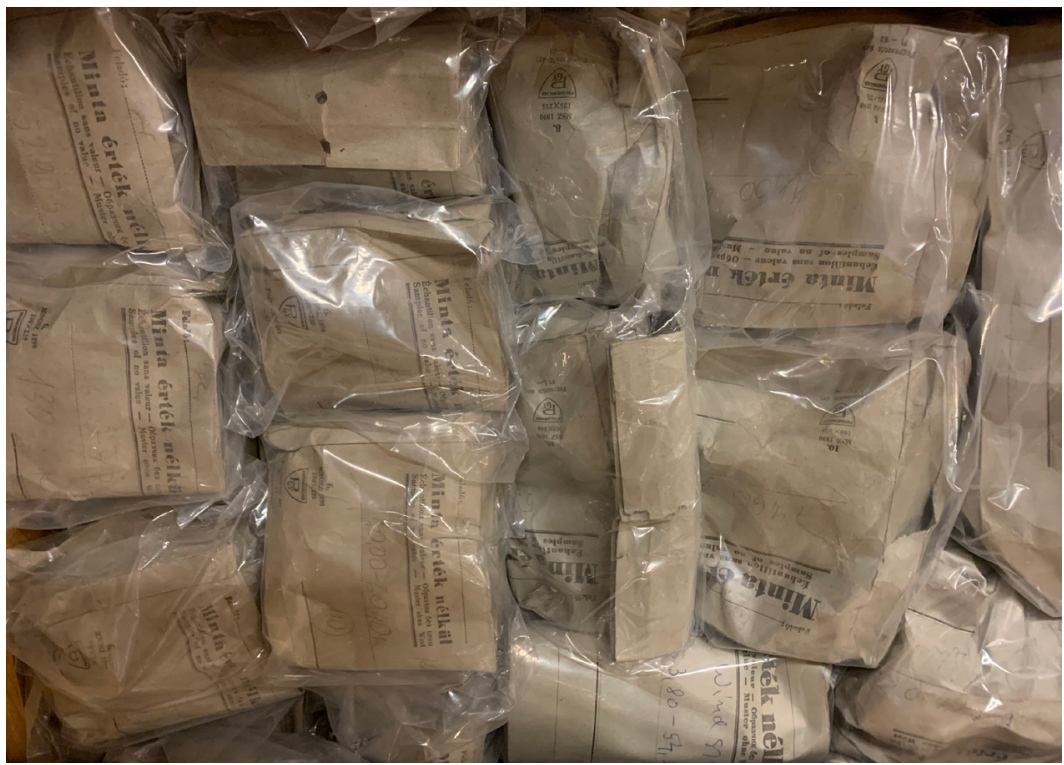

8.ábra. Miocén korú fúrási anyagok a Vizsgálatiminta Gyűjteményben. Igen fontos a mintaanyagok keveredésének megakadályozása, ezért az eredeti papírzacskóban lévő kőzetmintákat egy nylon zacskóba is becsomagoljuk. 
Szintén hatalmas anyagot képvisel a VMGY-ben a Deinas Gyüjtemény, melynek feldolgozása és nyilvántartásba vétele jelenleg is folyamatban van. Múzeumunk rendkívül gazdag ősmaradvány anyagot kapott ajándékba 2016-ban egy német házaspár, Jutta és Josef Deinas jóvoltából (Dula 2019b). Több mint 30 évnyi gyűjtőmunkájuk eredménye a hazai és külföldi lelőhelyekről származó, látványos mezozoós és kainozoós gerinctelen ősmaradvány anyag (mintegy 170 fiók külföldi és 203 fiók hazai anyag). A gyüjtemény egyik leglátványosabb részét alkotja a Párizsi-medencéből, Damery mellől származó középső-eocén (lutetiai) korú fauna, melyet részletesen is bemutattunk korábban (DuLAI et al. 2017).

A VMGY legutóbbi jelentősebb gyarapodása Dulai Alfréd nevéhez köthető, aki a hazai eocén és miocén lelőhelyek iszapolási mintái mellett törökországi eocén és recens üledékanyagokat helyezett el a gyűjteményben. Az utóbbi években szintén nagyon aktívan gyarapította az iszapolási mintákat Szabó Márton, aki a halfogak kutatása során gyüjtött számos hazai lelőhelyről.

A gyűjtemény gerinctelen ősmaradványokat tartalmazó üledékanyagai főként hazai geológusok magyarországi kutatásai és gyűjtései során kerültek be a gyüjteménybe. Egy fontos kivételt képez két holland magángyüjtő, Stef Mermuys és Henk Mulder gazdag miocén és pliocén anyaga különböző híres európai lelőhelyekről, akik Dulai Alfréd leideni kapcsolatainak köszönhetően ajándékozták a mintákat az Öslénytani és Földtani Tárnak. A miocén anyagok főleg Franciaországból (Corbleu, Moulin de Carro; Ferrière Larçon; Pauverlay; Sceaux-d'Anjou, La Presseliere) származnak, a leggazdagabb viszont a híres hollandiai Winterswijk-Miste lelőhely páratlan faunája. A pliocén ősmaradványokat Spanyolországban (Lucena del Puerto, Santa Catalina), Belgiumban (Deurganckdok; Verrebroekdok) és Olaszországban (Montaldo Roero, Trinita; Colle Val d'Elsa, Il Rudere; Castell d'Arquato, Torrente Arda) gyüjtötték. Erről a gyüjteményrészről részletes ismertetés található a Magyar Természettudományi Múzeum blogján (DUla 2016).

Szintén a külföldi vizsgálati mintákat gyarapítja Sztrákos Károly, Franciaországban élő magyar geológus gyüjteménye, aki Franciaországban gyüjtött, főleg mikrofosszíliákat (és kisebb részben eocén puhatestűeket) tartalmazó gyüjteményét adományozta a Magyar Természettudományi Múzeumnak (Dulai 2019b).

A fosszilis vizsgálati minták mellett elvétve recens anyagok is találhatók a gyűjteményben. A VMGY gerinctelen gyüjteményrészében került elhelyezésre Kázmér Miklós, az ELTE Öslénytani Tanszéke volt vezetőjének recens trópusi homokgyüjteménye, melyben tanulmányozható a tengerpartok mikroközössége. 


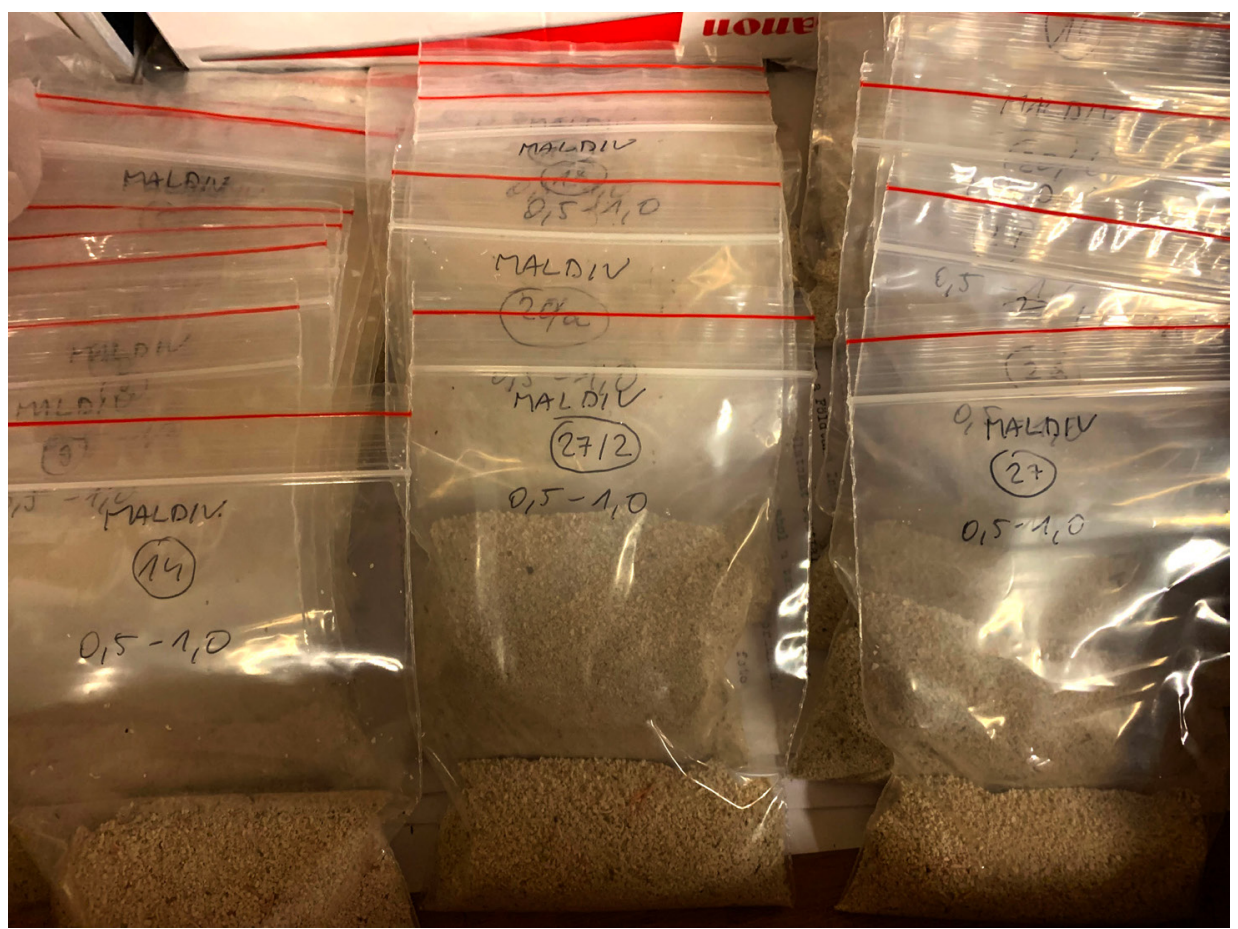

9. ábra. A Vizsgálatiminta Gyűjtemény recens anyagai (Kázmér Miklós gyűjteménye).

\section{A VIZSGÁLATIMINTA GYÜJTEMÉNY JELENTÖSÉGE}

A Vizsgálatiminta Gyüjtemény jelentősége a minták egy részének a pótolhatatlanságában rejlik: ebbeagyüjteményrészbe kerültugyanis minden olyan tétel, amely hazánkban az egykori nyersanyagkutató vagy alapfúrási programok során mélyült több ezer fúrás anyagából származik. Ezek az üledékminták, fúróminták, iszapolási maradékok sok esetben nem reprodukálható mintavétel során gyűjtött anyagokat képviselnek. Ezekből az üledékekből az Öslénytárban dolgozó kollégák gyakran csak egy-egy ősmaradvány-csoportot - például a nagyforaminiferákat - válogattak ki és dolgoztak fel, míg a többi, a mintában lévő mikroszkopikus ősmaradvány még kiválogatásra és feldolgozásra vár (lásd Dulai 2019a). A több száz, helyenként ezer métert is meghaladó mélységü mélyfúrások mikropaleontológiai-őslénytani vizsgálataihoz kapcsolódó zsákos üledékminták, vagy az egykori szénkutató eocén programhoz kapcsolódó hatalmas mennyiségủ fúrómag felszínre hozatala ma már nem kivitelezhetö, a gyüjtemény eszmei és tudományos értéke ezért felbecsülhetetlen. 
Olyan kőzetpéldányok vagy üledékanyagok is bekerültek a gyüjteménybe, melyek a felszínen többé nem tanulmányozhatóak vagy gyüjthetőek - jellemzően ilyenek a bányaművelés során felszínre kerülő jégkorszaki hasadékkitöltések és a barlangok üledékei, valamint a mára már természetvédelmi területté nyilvánított védett területekről származó anyagok. Ilyen minták esetében mindig felmerül, hogy esetleges későbbi (akár az anyagon eddig elvégzett vizsgálatokra, akár a tudományra nézve új) vizsgálati módszerek további fontos adatokkal szolgálhatnak, márpedig ezek csak a meglévő mintákon végezhetők el, ha időközben a lelőhely megsemmisült, eltűnt vagy nem hozzáférhető.

A VMGY azonban további perspektívát is rejt: nagyon sokszor idő- vagy szakember híján nem sikerül kellő alapossággal és mélységben feldolgozni egyegy lelőhely teljes anyagát, később azonban ez fokozatosan pótolható. Igen változatos módon kerültek feldolgozásra és publikálásra ilyen anyagrészek. Álljon itt néhány példa a gerinces gyüjteményrész pleisztocén korú anyagain végzett kutatások eredményeiből. OTKA kutatási pályázat során dolgoztuk fel a Jánossy Dénes által régebben begyüjtött Somssich-hegyi minták egy részét (PAZONY I et al. 2018, GASPARIK \& PAzONy 2018). Tudományos konferencián elhangzott elöadásban ismertettük a solymári Ördöglyuk-barlangból 2006 és 2007 során begyüjtött gerinces maradványokat (GASPARIK \& HANKó 2007).

Nemzetközi pályázatnak köszönhetően az Öslénytárba látogató külföldi vendégkutató a VMGY anyagából is válogatott ki olyan maradványokat, melyeket fontosnak ítélt a kutatásaihoz (MAYHEW 2009). Egyetemi szakdolgozó preparálta ki és dolgozta fel a beleltározatlan vértesszőlősi leletanyag egy részét.

Azt is megemlíthetjük, hogy tudományos ismeretterjesztő eseményeken, például múzeumpedagógiai foglalkozásokon, múzeumi közönségprogramokon rendszeresen bemutatjuk, illetve felhasználjuk a VMGY egyes részeit, így még inkább szélesedik az a paletta, ami ennek a gyüjteményrésznek az értékét és fontosságát demonstrálja. Annál is inkább fontos ez a demonstráció, mivel sajnos időről-időre, részben a Magyar Természettudományi Múzeum elhelyezési problémával összefüggésben is, felmerül a gyűjteményi terek szűkössége és a feldolgozatlan, emiatt külső szemlélők és döntéshozók által tévesen értéktelennek vélt gyüjteményrészek selejtezésének ötlete. Talán a fenti felsorolással megfelelően sikerült bemutatnunk, milyen értékektől fosztaná meg egy-egy ilyen selejtezés nem csak a múzeumot, hanem a tudományos közösséget és tágabb körben az őslénytan és földtan iránt érdeklődő nagyközönséget is.

$\mathrm{Ma}$ a gyüjtemény gyarapodása jelentős részben a terepi munkákhoz és a gyüjtésekhez köthető. Válogatás után az előkerült ősmaradványok a Rétegtani vagy a Gerinces és Gerinctelen Paleontológiai Gyűjtemény megfelelő gyüjteményrészébe kerülnek, a maradék üledékanyagot pedig a jövőbeni vizsgálatok céljából tovább őrzi a Vizsgálatiminta Gyűjtemény. Az Őslénytani és Földtani Tár továbbra is várja az érdeklődő kollégákat és a szakdolgozati témát kereső hallgatókat, valamint azokat, akik szakmai kutatási céllal keresnék fel a főleg mikropaleontológiai projektekre alkalmas Vizsgálatiminta Gyüjteményt. 


\section{HIVATKOZÁSOK}

Bitner M.A. \& Dulai A. 2008: Eocene micromorphic brachiopods from north-western Hungary. - Geologica Carpathica 59(1): 31-43.

Bosna Koff M. 2011: Cheklist of the fossil fish otoliths in the Department of Palaeontology and Geology, Hungarian Natural History Museum. - Fragmenta Palaeontologica Hungarica 29: 49-68.

Dula I A. 2015: Kiemelkedő miocén puhatestű adományok az Őslénytani és Földtani Tárnak. (Significant Miocene mollusc donations to the Department of Palaeontology and Geology.) - Annales Musei historico-naturalis hungarici 107: 207-220.

Dulai A. 2016: Holland magángyűjtők gazdag adománya az Őslénytárnak. - Magyar Természettudományi Múzeum Blog, https://mttmuzeum.blog.hu/2016/09/20/holland magangyujtok_gazdag_adomanya_az_oslenytarnak

Dulai A. (ed.) 2019a: Eocén élövilág a Kárpát-medencében. Üvegház - 22 millió éven át. Természettár Könyvsorozat, Budapest, 328 pp.

Dulai A. 2019b: Pazar adományok az Öslénytárnak. In: Dulai A. (ed.): Eocén élóvilág a Kárpát-medencében. Üvegház - 22 millió éven át., Természettár Könyvsorozat, Budapest, pp. 124-132.

Dulai A., Nónay F. \& Szabó M. 2017: Kivételes megtartású középső-eocén (lutetiai) fauna a Párizsi-medencéből (Damery). (Exceptional Middle Eocene (Lutetian) fauna from the Paris Basin (Damery.) - Annales Musei historico-naturalis hungarici 109: 147-170.

Jánossy D. 1979: A magyarországi pleisztocén tagolása gerinces faunák alapján. - Akadémiai Kiadó, Budapest, 207 pp.

Fözy I. (ed.) 2013: Late Jurassic-Early Cretaceous fauna, biostratigraphy, facies and deformation history of the carbonate formations in the Gerecse and Pilis Mountains (Transdanubian Range, Hungary). - GeoLitera, Szeged, 422 pp.

GASPARIK M. \& HAN Kó E. 2007: A solymári Ördöglyuk ragadozói. - Program, előadáskivonatok, kirándulásvezető, 10. Magyar Öslénytani Vándorgyülés, Budapest, pp. 19-20.

Gasparik M. \& Pazony P. 2018: The macromammal remains and revised faunal list of the Somssich Hill 2 locality (late Early Pleistocene, Hungary) and the Epivillafranchian faunal change. - Fragmenta Palaeontologica Hungarica 35: 153-178.

Kecskeméti T. 1970: Neue Nummulites-Arten aus dem Bakonygebirge (Transdanubien, Ungarn) I. Teil. - Annales historico-naturales Musei nationalis hungarici 62: 53-65.

Kecskeméti T. 2019a: Hantken Miksától az Eocén Programig: kutatástörténet. - In: Dulai A. (ed.): Eocén élövilág a Kárpát-medencében. Üvegház - 22 millió éven át, Természettár Könyvsorozat, Budapest, pp. 21-34.

Kecskeméti T. 2019b: Bezacskózott múlt: eocén fúrásminták. - In: Dulai A. (ed.): Eocén élövilág a Kárpát-medencében. Üvegház - 22 millió éven át, Természettár Könyvsorozat, Budapest, pp. 105-116. 
MAYHEW D. F. 2009: The type material and the enamel structure of Villanyia exilis Kretzoi, 1956 (Arvicolidae, Rodentia). - Acta Zoologica Cracoviensia 52A(1-2): 81-94.

Pazonyi P., Virág A., Gere K., Botfalvai G., Sebe K., Szentesi Z., Mészáros L., Bot Ka D., GASPARIK M. \& KoreCz L. 2018: Sedimentological, taphonomical and palaeoecological aspects of the late early Pleistocene vertebrate fauna from the Somssich Hill 2 site (South Hungary). - Comptes Rendus Palevol 17: 296-309.

Szives O. (ed.) 2007: Aptian-Campanian ammonites of Hungary. - Geologica Hungarica, series Palaeontologica 57: 1-187.

VöRös A. 1998: A Balaton-felvidék triász ammonoideái és biosztratigráfiája. (Triassic ammonoids and biostratigraphy of the Balaton Highland). - Studia Naturalia 12: 1-105.

Vörös A. 2003: The Pelsonian ammonoid fauna of the Balaton Highland. - In: Vörös A. (ed.): The Pelsonian Substage on the Balaton Highland (Middle Triassic, Hungary). - Geologica Hungarica, series Palaeontologica 55: 71-121.

Vörös A. 2018: The upper Anisian ammonoids of the Balaton Highland (Middle Triassic, Hungary). - Geologica Hungarica, series Palaeontologica 60: 1-240.

\title{
The Research Sample Collection of the Department of Palaeontology and Geology in the Hungarian Natural History Museum
}

\author{
Alfréd Dulai, Mihály Gasparik \& Ottilita Szives* \\ Hungarian Natural History Museum, Department of Palaeontology and Geology, \\ H-1083 Budapest, Ludovika tér 2-6, Hungary \\ E-mails:dulai.alfred@nhmus.hu,gasparik.mihaly@nhmus.hu,szives.ottilia@nhmus.hu
}

\begin{abstract}
Research Sample Collection in the Department of Palaeontology and Geology of the Hungarian Natural History Museum was established in 2011. The collection is mostly consist of core materials from boreholes, washed residuum samples or other types of sedimentary materials that have not undergone through sorting process but may contain useful paleontological or geological information. Scientific value of the Research Sample Collection is inestimable, as research and coal drilling projects are over in Hungary since decades, so the Research Sample Collection represent a unique, unreproductable collection of raw samples that may serve as a solid base for further palaeontological work. As usual at scientific museum collections, Research Sample Collection is divided into two main parts, samples (mostly sediments) that may contain invertebrate and which may contain vertebrate remains. These two units were subdivided

* corresponding author.
\end{abstract}


chronostratigraphically, moreover splitted by geographical regions. Vertebrate part of the Research Sample Collection was mostly collected in the mid20th century from caves or other, nowadays protected sites, therefore also represents a priceless value. Besides of scientific interest, use of special parts of the Research Sample Collection is broad, including educational, museum pedagogy and social event purposes, demonstrating other values besides the science. However, in connection with the lack of space, or the forthcoming move of the whole museum, from time to time an idea of scrapping this collection arises. As hereby it is demonstrated, this would be an irrecoverable loss not just for the national and international scientific community, but for the general public interested in palaeontology. With nine figures.

Key words - fossil, museum, collection, washed residuum, borehole

\section{FIGURE CAPTIONS}

Figure 1. Documentation and deposition of the Reserch Sample Collection by cabinet cadastral order.

Figure 2. Vertebrate reserach materials from the localities Beremend and Vértesszőlös, as curated in the Reserch Sample Collection.

Figure 3. Snapshot from the research phases of a veretbrate material from Cukor-bánya (locality Süttő): samples investigated and determined by David Mayhew.

Figure. 4. Reserch Sample Collection is in the focus of international vertebrate research: small mammal fragments from locality Villány- 4 identified by David Mayhew.

Figure 5. Upper Jurassic ammonites from the locality Eperkéshegy (Zirc) (collected by István Főzy).

Figure 6. Ammonites from Mexico and Argentina, Collected by J. Pálfy and I. Főzy.

Figure 7. Sorted and identified samples from Eocene cores, collection of Tibor Kecskeméti.

Figure. 8. Miocene samples from the Reserch Sample Collection. In order to avoid mixing of research sample materials, their double wrapping in two nylon sacks is needed.

Figure 9. Recent materials from the Maldives, collected by Miklós Kázmér. 